\title{
ASSESSMENT OF CASSAVA PROCESSING TECHNOLOGIES USAGE AMONG RURAL WOMEN IN KWARA STATE, NIGERIA
}

\author{
A.O. AWOYEMI ${ }^{1}$, , O.J. ADESOKAN ${ }^{1}$, A.O. KAYODE ${ }^{1}$, \\ K.F. OMOTESHO ${ }^{1}$, K.K. OSASONA ${ }^{2}$ \\ *E-mail: awoyemi.oa@unilorin.edu.ng
}

Received: Apr. 25, 2020. Revised: June 30, 2020. Accepted: July 13, 2020. Published online: Oct. 16, 2020

\begin{abstract}
Technology usage has been identified as a major driver of increased productivity, waste management and economic efficiency. However, there seems to be some barriers to technology usage among rural women cassava processors Nigeria. This study therefore analysed the characteristics and constraints to technology usage among rural women processors in Ifelodun local government area of Kwara State, Nigeria. A two-stage sampling technique was used to randomly select 120 respondents from six districts, namely Igbaja, Idofin, OkeOde, Omupo, Ora and Share. Primary data were used for the study and the data were collected by means of an interview schedule. Descriptive statistical tools, such as precision counts, frequencies and percentages, were used in analysing the data, while Pearson Product Moment Correlation (PPMC) analysis was used to test the hypothesis. The findings revealed the level of usage of cassava processing
\end{abstract}

among rural women in the study area is moderately high. Major constraints to the adoption of cassava processing technologies includes: high cost of machines and maintenance, low level awareness and training, as well as inadequate finance. PPMC analysis showed that educational level and cassava processing experience was significantly related to the usage of improved cassava processing technologies in the study area with $p \leq 0.05$. Based on findings, training and effective monitoring by relevant stakeholders, adequate financing, sensitization and enlightenment campaigns will further boost cassava processors knowledge and attitude towards cassava processing technologies and automatically increase usage by the respondents.

Keywords: increased productivity; characteristics; adoption, constraints.

\footnotetext{
${ }^{1}$ Department of Agricultural Extension and Rural Development, University of Ilorin, Ilorin, Nigeria

${ }^{2}$ Department of Agricultural Economics and Farm Management, University of Ilorin, Ilorin, Nigeria
} 


\section{INTRODUCTION}

Technology adoption and usage have positive connotations among policy-makers and the public at large. It is often associated with waste management, time management, speed, higher income and efficiency. Access to the extension service delivery (ESD) has been identified as one of the major driver of technological usage. However, in most rural settings, especially in SubSaharan Africa, access to sufficient knowledge, improved technology, financial services and other important social services remain a critical issue (Mbo'o-Tchouawou and Colverson, 2014). There are still significant challenges in providing adequate extension and advisory services (EAS) in these areas. These range from insufficient fund for supporting public extension, poor resourcing.

Agriculture in Nigeria is dominated by small scale farmers, who produce about $80 \%$ of the total food requirement (Fayinka, 2004). These farmers are characterized by strong dependence on agricultural labour market, little or no form of savings or storage facilities and cultural practices adopted are highly labour intensive (Idachaba, 1995; Festus, 2005; Fakayode, 2008). The goal of agricultural extension services in Nigeria is to facilitate farmers acceptance, while the ultimate goal of agricultural extension is to improve standard of living through the transfer of improved farming practices to the rural people.
Cassava (Manihot esculenta) is the third most important food crop in the tropics after rice and maize, and it is consumed daily by up to one billion people, mostly in sub-saharan Africa (Terry and Otim-Nape, 2012). Cassava is a major staple food widely cultivated in the lowland humid tropic and it is capable of providing very high yields of energy per hectare. Cassava is a versatile crop; all parts of the plant including its root have been processed into a number of products. These include food for human consumption, animal feeds and industrial based products. Cassava based diets are main sources of dietary energy. Cassava food products include garri, lafun, fufu, flour, tapioca and chips. Dextrins, starch, syrups, alcohols and dextrose are products from cassava. Some of these serve as raw materials in different industries (Ashaye et al., 2007). It has contributed significantly to alleviation of food crisis in Nigeria because of its efficient production of food energy all year round, availability, tolerance to extreme stress conditions, and suitability to peasant farmers who are the mainstay of food systems in the country. Nigeria currently produces about 54 million metric tonnes per annum (FAO, 2013), making her the highest cassava producer in the world, producing a third more than Brazil and almost double the production capacity of Thailand and Indonesia. However, Nigeria is not an active participant in cassava trade in the international markets because most of her cassava is targeted at the domestic food market. 
The production methods are primarily subsistence in nature and therefore unable to support industrial level demands (FAO, 2013). More than 248 million tons of cassava was produced worldwide in 2012 of which Africa accounted for 58\% (IITA, 2012).

Women play a central role in cassava production, harvesting, processing and marketing contributing about $58 \%$ of the total agricultural labour in the southwest, $67 \%$ in the southeast and $58 \%$ in the central zones (FAO, 2004; Onyemauwa, 2012). Never before in the Nigerian history has the necessity for educating and raising the productive capacity of our farmers been of such importance than it is today. Increased agricultural productivity depends primarily upon the acceptance of cultural and technological changes at the rural farm level. It has been observed that the farmers have mostly found it difficult to respond to the new technologies due to the fact that the technologies are costly to acquire and maintain and also that they are not properly educated and this has been a very big constraint, especially for the rural women. This automatically affects the level of usage of the extension service delivery available to them and in turn barring them from maximally enjoying the benefits of these new technologies.

The broad objective of this study was to assess the characteristics and constraints to cassava processing technologies usage among rural women in Ifelodun local government area of Kwara State. The specific objectives for this research were to describe the socio-economic characteristics of the women cassava processors in the study area, examine the cassava processing technologies available and their level of usage among women cassava processors in the study area, identify the effect of agricultural extension information on cassava processing technology usage in the study area, and identify the constraints of the rural women cassava processors to usage of the available cassava processing technologies.

\section{MATERIALS AND METHODS}

The study was conducted in Ifelodun local government area of Kwara State, Nigeria. A two-stage random sampling technique was used to select 120 respondents for the study. The first stage was a random selection of two communities each from six out of the eight districts of the Local Government Area which are Igbaja, Idofin, Oke-Ode, Omupo, Ora and Share. The second stage involved a random selection of 10 women cassava processors in each of the selected communities of the Local Government Area to make a total sample size of 120 women cassava processors as respondents. Data collected was organized and analysed through tables, percentages, mean and frequency counts and Pearson Product Moment Correlation (PPMC).

\section{RESULTS AND DISCUSSION}

Table 1 shows the socio-economic characteristics of the respondents with their mean age to be 45 years. This suggests that they belong to the economically active population category. They can therefore put more 
effort into cassava processing in order to increase their output. Furthermore, the study shows that majority $(93.3 \%)$ of the respondents have some forms of education. This implies that the processors are likely to readily adopt new technologies and innovations. It was also observed that more than half $(69.1 \%)$ of the respondents have between 11-30 years of cassava processing experience with a mean value of 18.3 years. It suggests that the processors are not new to the business of cassava processing.

Table 1 - Distribution of the respondents by their socio-economic characteristics $(n=120)$

\begin{tabular}{llll}
\hline Variables & Frequency & Percentage (\%) & Mean \\
\hline Age (years) & & & \\
\hline $21-30$ & 3 & 2.5 & 45.1 years \\
\hline $31-40$ & 36 & 30.0 & \\
\hline $41-50$ & 50 & 41.7 & \\
\hline $51 \&$ above & 31 & 25.8 & \\
\hline Marital status & & & \\
\hline Married & 96 & 80.0 & \\
\hline Separated & 3 & 2.5 & \\
\hline Divorced & 3 & 2.5 & \\
\hline Widowed & 18 & 15.0 & \\
\hline Educational status & & & \\
\hline Non formal education & 8 & 6.7 & \\
\hline Primary education & 60 & 50.0 & \\
\hline Secondary education & 52 & 43.3 & \\
\hline Household size & & & \\
\hline $1-5$ & 34 & 28.3 & \\
\hline $6-10$ & 84 & 70.0 & \\
\hline $11-15$ & 2 & 1.7 & \\
\hline $\begin{array}{l}\text { Cassava processing } \\
\text { experience }\end{array}$ & & & \\
\hline $1-10$ & 29 & 24.2 & \\
\hline $11-20$ & 52 & 43.3 & \\
\hline $21-30$ & 31 & 25.8 & \\
\hline
\end{tabular}

Table 2 shows that the pressing (100\%), grating (100\%), dewatering $(92.5 \%)$ and milling (99.2\%) machines are the cassava processing technologies available to majority of the respondents. It implies that both the pressing and grating machines are available to every cassava processor in this area. It also shows that both the dewatering and milling machines are very much available to almost all the cassava processors. This ultimately implies that with the availability of these various machines, processing of cassava will be enhanced and with less stress and labour. 


\section{A.O. AWOYEMI, O.J. ADESOKAN, A.O. KAYODE, K.F. OMOTESHO, K.K. OSASONA}

Table 2 - Distribution of the respondents by the cassava processing technologies available in the study area

\begin{tabular}{lll}
\hline $\begin{array}{l}\text { Cassava processing } \\
\text { technologies available }\end{array}$ & Frequency & Percentage (\%) \\
\hline Cassava peeler & 37 & 25.8 \\
\hline Pressing machine & 120 & 100 \\
\hline Grating machine & 120 & 100 \\
\hline Dewatering machine & 111 & 92.5 \\
\hline Milling machine & 119 & 99.2 \\
\hline Sifting machine & 73 & 60.8 \\
\hline Mechanical sieve & 42 & 35.0 \\
\hline Dryer & 24 & 20.0 \\
\hline Fryer & 32 & 26.7 \\
\hline
\end{tabular}

Source: Field survey, 2019; *multiple responses

Following the methodology of Enete and Amusa (2010), the mean score of the responses was used to judge the level of usage as low, moderate and high. Mean scores less than 2.5 is adjudged as low, mean scores of $2.50-3.50$ as moderate and mean scores greater than 3.50 as high. Therefore, Table 3 shows that the level of usage of cassava peeler, mechanical sieve, dryer and fryer is low, the level of usage of sifting machine is moderate and the level of usage of pressing, grating, dewatering and milling machine is high. This implies that the respondents have ultimately adopted the grating, pressing, dewatering and milling machines and often use them.

Table 3 - Distribution of the respondents by their level of usage of cassava processing technologies available in the study area

\begin{tabular}{lccccccc}
\hline $\begin{array}{l}\text { Level of } \\
\text { usage }\end{array}$ & $\begin{array}{c}\text { Very low } \\
(\%)\end{array}$ & $\begin{array}{c}\text { Low } \\
(\%)\end{array}$ & $\begin{array}{c}\text { Average } \\
(\%)\end{array}$ & $\begin{array}{c}\text { High } \\
(\%)\end{array}$ & $\begin{array}{c}\text { Very } \\
\text { high (\%) }\end{array}$ & $\begin{array}{c}\text { Mean } \\
\text { score }\end{array}$ & $\begin{array}{c}\text { Ran } \\
\mathbf{k}\end{array}$ \\
\hline $\begin{array}{l}\text { Cassava } \\
\text { peeler }\end{array}$ & $79(65.8)$ & $28(23.3)$ & $11(9.2)$ & $2(1.7)$ & - & 1.07 & $9^{\text {th }}$ \\
\hline $\begin{array}{l}\text { Pressing } \\
\text { machine }\end{array}$ & $1(0.8)$ & - & - & $68(56.7)$ & $51(42.5)$ & 4.40 & $2^{\text {nd }}$ \\
\hline $\begin{array}{l}\text { Grating } \\
\text { machine }\end{array}$ & - & - & - & $47(39.2)$ & $73(60.8)$ & 4.60 & $1^{\text {st }}$ \\
\hline $\begin{array}{l}\text { Dewatering } \\
\text { machine }\end{array}$ & $1(0.8)$ & $10(8.3)$ & $3(2.5)$ & $59(49.2)$ & $47(39.2)$ & 4.18 & $4^{\text {th }}$ \\
\hline $\begin{array}{l}\text { Milling } \\
\text { machine }\end{array}$ & $2(1.7)$ & $1(0.8)$ & $8(6.7)$ & $50(41.6)$ & $59(49.2)$ & 4.36 & $3^{\text {rd }}$ \\
\hline $\begin{array}{l}\text { Sifting } \\
\text { machine }\end{array}$ & $27(22.5)$ & $24(20.0)$ & $6(5.0)$ & $46(38.3)$ & $17(14.2)$ & 3.01 & $5^{\text {th }}$ \\
\hline $\begin{array}{l}\text { Mechanical } \\
\text { sieve }\end{array}$ & $75(62.5)$ & $20(16.7)$ & $10(8.3)$ & $10(8.3)$ & $5(4.2)$ & 1.75 & $6^{\text {th }}$ \\
\hline Dryer & $89(74.1)$ & $22(18.3)$ & $6(5.0)$ & $3(2.5)$ & - & 1.35 & $7^{\text {th }}$ \\
\hline Fryer & $96(79.9)$ & $11(9.2)$ & $11(9.2)$ & $2(1.7)$ & - & 1.32 & $8^{\text {th }}$ \\
\hline
\end{tabular}

Source: Field survey, 2019 
Table 4 shows that high cost of machine (2.98) and high maintenance cost (2.97) are the major constraints to the usage of extension information in the study area. This implies that majority of the respondents could not afford the machines needed for cassava processing and some that could afford to buy the machine cannot afford the cost of maintenance. It also showed that erratic power supply (1.79) serves as a constraint to the usage of the technologies, but it does not pose a serious effect.

Table 4 - Distribution of the respondents by the constraint to the usage of improved cassava processing technologies

\begin{tabular}{lcccccc}
\hline Constraints & $\begin{array}{c}\text { No effect } \\
(\%)\end{array}$ & $\begin{array}{c}\text { Fair effect } \\
(\%)\end{array}$ & $\begin{array}{c}\text { Moderate } \\
\text { effect (\%) }\end{array}$ & $\begin{array}{c}\text { Serious } \\
\text { effect (\%) }\end{array}$ & $\begin{array}{c}\text { Mean } \\
\text { score }\end{array}$ & Rank \\
\hline $\begin{array}{l}\text { High cost of } \\
\text { machine }\end{array}$ & - & - & $3(2.5)$ & $117(97.5)$ & 2.98 & $1^{\text {st }}$ \\
\hline $\begin{array}{l}\text { High maintenance } \\
\text { cost }\end{array}$ & - & - & $4(3.3)$ & $116(96.7)$ & 2.97 & $2^{\text {nd }}$ \\
\hline $\begin{array}{l}\text { Erratic power } \\
\text { supply }\end{array}$ & $34(28.3)$ & $8(6.7)$ & $27(22.5)$ & $51(42.5)$ & 1.79 & $7^{\text {th }}$ \\
\hline $\begin{array}{l}\text { High operational } \\
\text { cost of home } \\
\text { machines }\end{array}$ & - & $3(2.5)$ & $22(18.3)$ & $95(79.2)$ & 2.77 & $4^{\text {th }}$ \\
\hline $\begin{array}{l}\text { Inadequate water } \\
\text { supply }\end{array}$ & $29(24.1)$ & $39(32.5)$ & $38(31.7)$ & $14(11.7)$ & 1.31 & $8^{\text {th }}$ \\
\hline $\begin{array}{l}\text { Low level of } \\
\text { education }\end{array}$ & - & $3(2.5)$ & $23(19.2)$ & $94(78.3)$ & 2.76 & $5^{\text {th }}$ \\
\hline $\begin{array}{l}\text { Complexity of } \\
\text { machine } \\
\text { Operation }\end{array}$ & - & $3(2.5)$ & $17(14.2)$ & $100(83.3)$ & 2.81 & $3^{\text {rd }}$ \\
\hline $\begin{array}{l}\text { Inadequate credit } \\
\text { facilities }\end{array}$ & - & $1(0.8)$ & $52(43.3)$ & $67(55.9)$ & 2.55 & $6^{\text {th }}$ \\
\hline
\end{tabular}

Source: Field survey, 2019

\section{CONCLUSION AND RECOMMENDATION}

The study therefore concludes that the level of usage of cassava processing among rural women in the study area is moderately high. The study however shows that the respondents have really benefitted from the available cassava processing technologies in the area. Based on findings, training and effective monitoring by relevant stakeholders, adequate financing, sensitization and enlightenment campaigns will further boost cassava processors knowledge and attitude towards cassava processing technologies and automatically increase usage by the respondents. It is further recommended that cassava processors should be properly educated on the inherent benefits in the adequate usage of the improved cassava processing technologies. 


\section{REFERENCES}

Ashaye, O.A, Obatolu, V.A, Amusa, N.A, Fasoyiro, S.B. \& Ayoola, T.A. (2007). Tips and strategies for profitable cassava production, processing and export. Rashmed Publication Ltd., Ibadan, p.69.

Enete, A.A. \& Amusa, T.A. (2010). Contribution of men and women to farming decisions in cocoa based agroforestry housholds of Ekiti State, Nigeria. Tropicultura, 28(2): 77-83.

Fakayode, S.B, Babatunde R.O. \& Ajao, R. (2008). Productivity analysis of cassava - based production systems in the Guinea Savannah: Case study of Kwara State, Nigeria. AmEuras.J.Sci.Res., 3 (1): 33-39, IDOSI Publications.

FAO (2004). Cassava industrial revolution in Nigeria. www.fao.org/docrep007/ y5548e/y5548e07htm

FAO (2013). Food and Agriculture Organization of the United Nations. Statistical Database - FAOSTAT, http://faostat.fao.org/; [Accessed 14 July 2013].

Fayinka, F.A. (2004). Food security in Nigeria: Challenges under democratic dispensation. Paper presented at the $9^{\text {th }}$ ARMTI Annual Lecture, Ilorin, March 24.

Festus, A (2005). Unveiling Kwara's white farmers. Sunday Punch $17^{\text {th }}$ July, p. 35.

Idachaba, F.S. (1995). Food for all Nigerians: Is there hope? Alumni Lecture, University of Ibadan, Nigeria.

IITA (2012). An annual report on cassava production, pp. 4-6.

Mbo'o-Tchouawou, M. \& Colverson, K.E. (2014). Increasing access to agricultural extension and advisory services: How effective are new approaches in reaching women farmers in rural areas? ILRI Project Report. Nairobi, Kenya: ILRI.

Onyemauwa, C.S. (2012). Analysis of women participation in cassava production and processing in Imo State, Southeast Nigeria, Agric.Trop.Subtrop., 45(2): 72-77, DOI: 10.2478/v10295-012-0012-9

Terry, E.R. \& Otim-Nape, G.W (2012). Cassava as food security and industrial crop - Challenges and opportunities for Africa. 